\title{
USER EXPERIENCE ANALYSIS OF SMART PHONE USERS IN EXPLORING AND READING NONFICTION BOOKS
}

\author{
Fuad Wahdan Muhibuddin*)1, Popong Nurhayati*), and Mohamad Sahid Rahman*) \\ *) School of Business, IPB University \\ Jl. Pajajaran, Bogor 16151
}

\begin{abstract}
Indonesia has a high penetration users of smart phone occupied 4th position behind China, India, and US. The utilization of smart phone should be contributed positive matter to its users, once increasing reading habbit. We argued that so important to user to find some nonfiction books information related to their needs and desires, and high potential platform business model development. This paper aims to map a relation between users experience in exploring and reading of nonfiction books to platform business development opportunities. The study was human centre and qualitative approach, conducted by user experience analysis with empathy mapping canvas and customer journey mapping approach, then conducted mind mapping for synthesis problems as user experiences. The result shown the frequently user problems are lacked of nonfiction books information, lacked of reading motivation, constrained on purchasing or rent the book, lacked of book reading management. By solving those problems should drive to ideate developing platform based human centered design and shown highly potential market platform for special user book reader and generally smart phone users.
\end{abstract}

Keywords: user experience, human centre, empathy map canvas, customer journey mapping

Abstrak: Indonesia yang memiliki penetrasi pengguna ponsel pintar yang tinggi menduduki posisi ke-4 di belakang China, India, dan AS. Pemanfaatan ponsel pintar harus memberikan kontribusi hal yang positif bagi penggunanya, sekaligus meningkatkan kebiasaan membaca. Kami berpendapat bahwa sangat penting bagi pengguna untuk menemukan beberapa informasi buku nonfiksi terkait dengan kebutuhan dan keinginan mereka, dan pengembangan model bisnis platform berpotensi tinggi. Makalah ini bertujuan untuk memetakan hubungan antara pengalaman pengguna dalam mengeksplorasi dan membaca buku nonfiksi dengan peluang pengembangan bisnis platform. Penelitian yang dilakukan adalah pendekatan human center dan kualitatif, dilakukan analisis pengalaman pengguna dengan kanvas pemetaan empati dan pendekatan pemetaan perjalanan pelanggan, kemudian dilakukan pemetaan pikiran untuk sintesis masalah sebagai pengalaman pengguna. Hasil penelitian menunjukkan permasalahan pengguna yang sering terjadi adalah kurangnya informasi buku nonfiksi, kurangnya motivasi membaca, terkendala dalam membeli atau menyewa buku, kurangnya manajemen membaca buku. Dengan memecahkan masalah tersebut harus mendorong untuk mengembangkan platform berbasis desain yang berpusat pada manusia dan menunjukkan platform pasar yang sangat potensial untuk pembaca buku pengguna khusus dan umumnya pengguna ponsel pintar.

Kata kunci: pengalaman pengguna, pusatmanusia, kanvas peta empati, pemetaan perjalanan pelanggan

\footnotetext{
${ }^{1}$ Corresponding author:

Email: fuadwahdan@apps.ipb.ac.id
} 


\section{INTRODUCTION}

Nowadays Indonesia has a high penetration users of smart phone occupied 4th position behind China, India, and US. Indonesia In 2021 projected 86.21 million smart phone user, increased 5.3\% from 2020 and those number continued to raise every year (Statista 2020). This incremental should be contributed positive matter to its user, once reading nonfiction book to up scaling either knowledge or soft skill. That matter could be happen due to smart phone technology able to make easier for various groups of people to access reading sources.

Meanwhile, Indonesia reading index is low (The Ministry of Education and Culture 2019). Central Connecticut State University (CCSU) in March 2016 reported Indonesia was ranked 60th in reading interest index out of 61 countries. The Program for International Student Assessment (PISA) survey which conducted by the Organization for Economic Co-Operation and Development (OECD) in 2018 informed that Indonesia ranked was 75 th for reading category out of 80 countries.

In spite of lack of reading self motivation, Indonesian generally has not utilized smart phone for reading nonfiction books as well. In other hand, smart phone users were constrained by lack of a platform which supporting book readers. Refers to conditions described above, developing platform might encourage smart phone user especially book reader to explore and read nonfiction books everywhere and every time.

Platform businesses changed the dynamics of a market as mentioned by Jonash, Koehler, and Onassis (2007). Kim (2015) pointed platforms, exceedingly important technological and strategical innovations in the new millennium, have had an enormous impact on sustainable growth and have affected the ICT and other industries. Evans and Schmalensee (2007) based on Kim (2015) pointed out that 21 platforms have not only a definitive role in the ICT industry, but also in other industries such as media, finance, and distribution.

Kotler and Armstrong (2010) argue in modern business, companies are confronted with various environmental changes, such as competitive market structures, technological issues, competitive advantages, and public policies. These changes frequently require companies to adapt their business models significantly to overcome these alterations in the environment. Designed a platform should be considered to user needs and desire, thus met to the market and hence a competitive advantage.

Gray (2017) stated empathy map is a human-centred design toolkit developed by XPLANE a design consulting company. The empathy map was created to help a team share the same understanding with customers. Empathy maps are also often used to improve customer experience, to navigate political organizations, to design work environments, and many others.

Customer journey mapping is the representation, in a flowchart or other graphic format, of the customer's experience as he or she interacts with your company in receiving its product or service. These maps can depict the customer's actual or ideal journey. Either way, plotting its stages forces you to focus on your customers, rather than on your organization. The journey map is a powerful tool to shift your focus from "What does my company want?" to "What is the customer trying to do?" It invites problem-solving teams to form a strong empathetic connection with the customer, not as a data point or a demographic, but as an individual with hopes and challenges worth considering (Liedtka and Ogilvie, 2011). The purpose of this study is to identify and describe the problems / user experience analysis of smart phone user in exploring and reading nonfiction books.

\section{METHODS}

The study about user experience analysis was conducted human centere design approach, which is descriptive with qualitative analysis adopted from Liedtka and Ogilvie (2011) framework. According to Wahyuni (2016), Tajibu (2013) and Punch (2013) descriptive research is research that aims to explain specific problems or objects in detail. This study focuses on identifying the user experience of smart phone user in exploring and reading nonfiction books using empathy map canvas, customer journey mapping, and mind mapping.

The study was conducted in Bogor from March to August 2020. Data collected using descriptivequantitative approach, and there were two types of data used are primary data and secondary data. Primary 
data obtained through online survey due to pandemic of COVID 19. While secondary data obtained from literature review. The research instrument used for primary data collection was a questionnaire. Sampling method in this study used non-probability sampling approach through purposive sampling techniques and snowball sampling were adopted from Wahyuni (2016) and Punch (2013). The number of respondents was 30 persons with criteria 1) smart phone user, 2) domiciled in Bogor, 3) having problem on reading nonfiction books. Snowball sampling used to facilitate searching another respondents whose met with criteria.

Empathy map canvas adopted from Gray (2017) there are seven blocks of questions to help empathize with the user which developed the questionnaire. The seven blocks question consist of 1) who are we empathizing with?, 2) what do they need to do?, 3) What do they you see?, 4) What do they say?, 5) What do they do?, 6) What do they hear?, 7) What do they think and feel? Customer journey adopted from (Liedtka and Ogilvie, 2011) obtained from empathy map then mapped in to customer journey map.

\section{RESULTS}

Nowadays platform business has been developed since the hype growth of IOT. Jonash, Koehler, and Onassis (2007) and Kim (2015) mentioned that platform business changed the dynamic of a market, have had an enormous impact on sustainable growth and have affected the ICT and other industries. The other hand, the spread of Corona virus is driving forced changed the way world work. The people should distanced by another and made new shifting utilized the IOT. So, develop a platform today is huge potential business.

The study of user experience used widely to develop a platform. It used an empathic process approach to obtain insight about problems faced by customer. It made a competitive advantage in dynamic platform market. In this study empathic process approach conducted by empathy map canvas and customer journey.

\section{Empathy Map Canvas}

The purpose of empathy map canvas is to map an identified user problem obtained through seven block questions. The result of empathy map canvas shown in Figure 1.

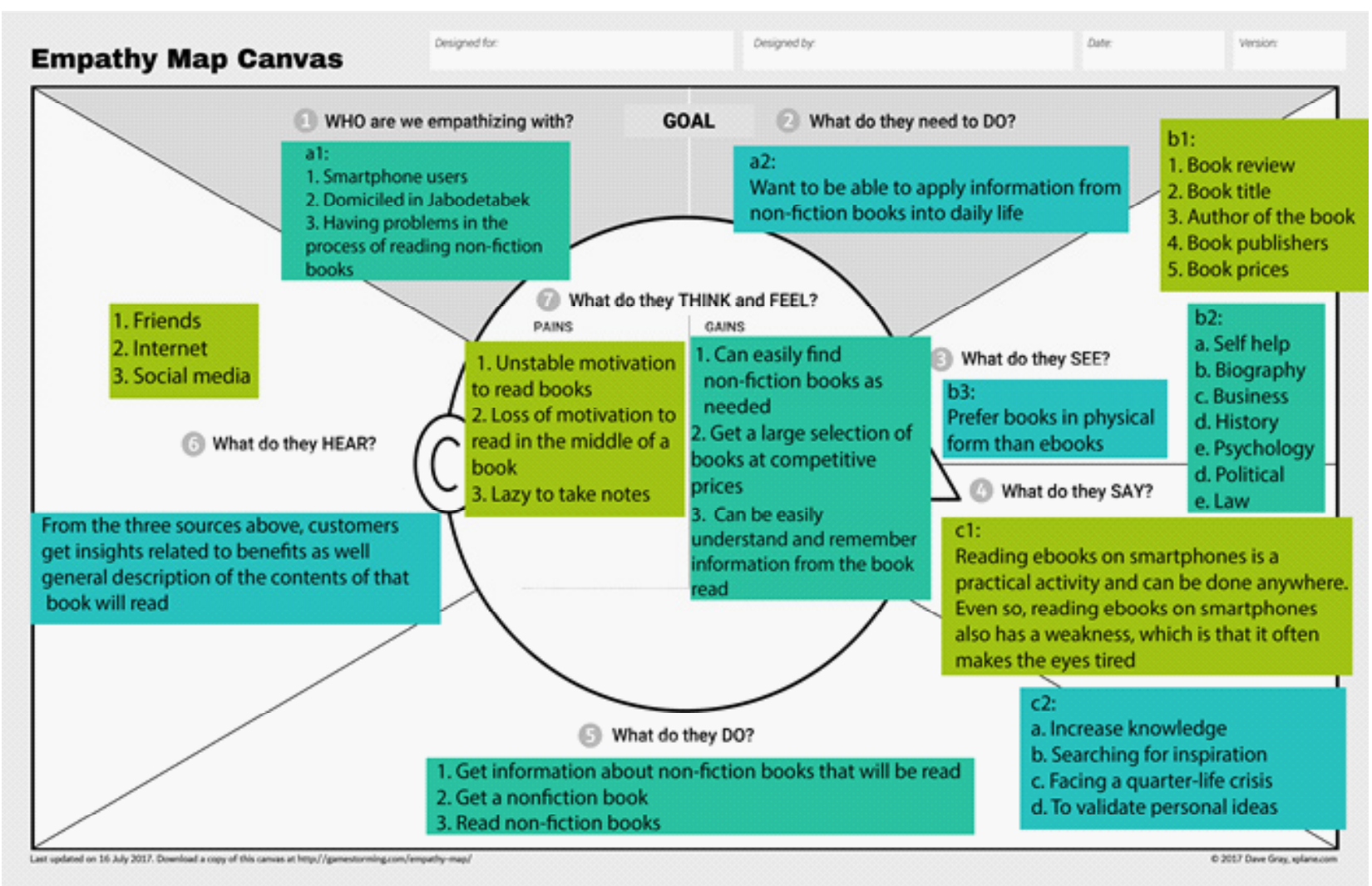

Figure 1. Empathy map canvas smart phone user (Gray, 2017) 


\section{A. Goal}

a1. Who are we empathizing with?: In this study was focused on identifying the problems experienced by smart phone users in the process of reading nonfiction books. The criteria for respondents / customers are smart phone users, live in Bogor and having problems in the process of reading nonfiction books.

a2. What do they need to do?: This section described what the customer wants to achieve from the whole process of reading a nonfiction book. Based on the results found that all customers have the same desire, they want to be able to use the knowledge and information from nonfiction books into their daily lives as up scaling knowledge and skill.

B. What do they see?: This section describes three things, namely (b1) factors that customers pay attention when reading nonfiction books, such as book review, book title, book author, book publisher, book price; (b2) Nonfiction book themes that customers preferred; (b3) The form of the book that most customers preferred.

C. What do they say?: This section describes two things, they are (c1) Customer opinion regarding reading e-books on smart phones; (c2) Things that motivate customers to read nonfiction books.

D. What do they do?: This section described the stages during the process of reading a nonfiction book. The process of reading nonfiction books is divided into three stages, such as (1) Obtained information on nonfiction books to be read; (2) Obtained a nonfiction book to be read; (3) Read nonfiction books. A description of the activities carried out in each stage can be seen in the sub subchapter of the customer journey map.

E. What do they hear?: This section described what opinions are heard by customers regarding non-fiction books, starting from the source of information on nonfiction book recommendations and what insights customers get when they get information on nonfiction book recommendations

F. What do they think and feel?: This section describes the problems experienced by customers, as well as customer expectations during the process of reading nonfiction books.

\section{Customer Journey Map}

Customer journey map were used to remap the information obtained from empathy map canvas in order to customer journey could be mapped clearly. The customer journey map has there stages that the customer will go through defined from empathy map - "what they do?" section as followed (1) Obtained information on nonfiction books to be read; (2) Obtained a nonfiction book to be read; (3) Read nonfiction books. The study found the customer feelings through the journey of reading nonfiction books that customer was not happy when reading book on the smart phone, and normal feeling for stage obtained information nonfiction book and stage obtained a nonfiction book. The customer feeling journey shown in Figure 2. The problems explanation of customer journey in each stage followed as activities, customer problem, and customer expectation shown in Table 1.

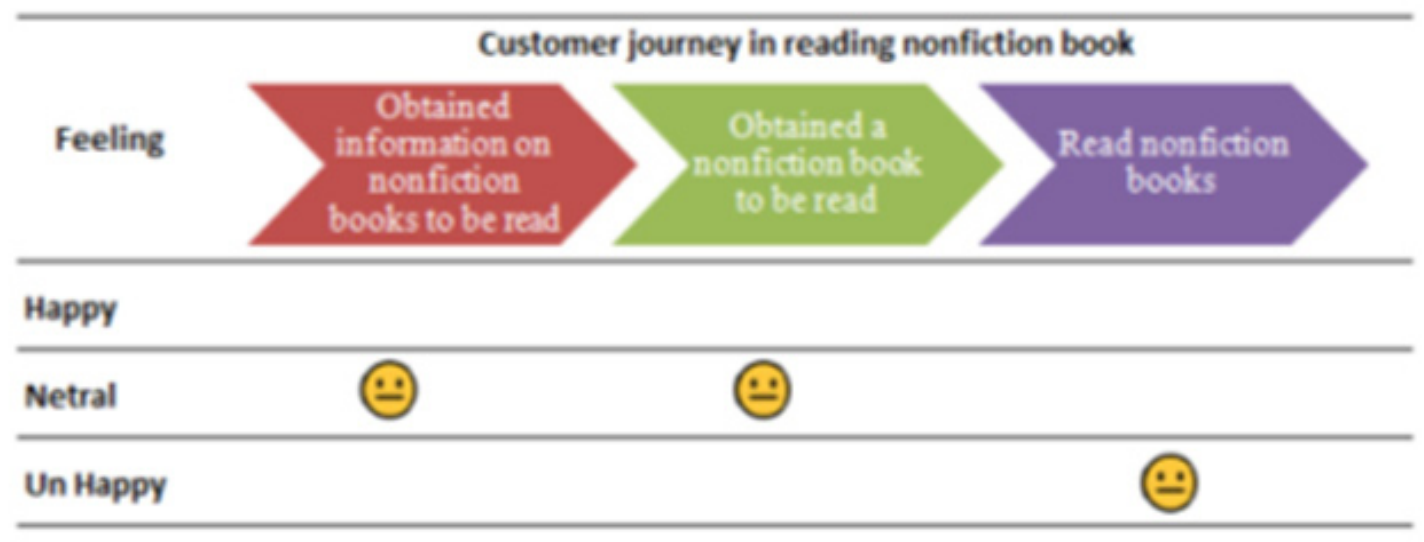

Figure 2. Customer feeling journey 
Table 1. The customer journey in the process of reading a nonfiction books

\begin{tabular}{|c|c|c|c|}
\hline Stages & $\begin{array}{l}\text { 1. Get information about non-fiction } \\
\text { books }\end{array}$ & 2. Get a non-fiction book & 3. Read a non-fiction book \\
\hline Activities & $\begin{array}{l}\text { 1. Looking for book title } \\
\text { recommendation } \\
\text { 2. Looking for book reviews }\end{array}$ & $\begin{array}{l}\text { A. Buy books } \\
\text { B. Borrowing book } \\
\text { C. Download books* }\end{array}$ & $\begin{array}{l}\text { 1. Find a place that is conducive to } \\
\text { reading a book } \\
\text { 2. Make highlights and notes }\end{array}$ \\
\hline $\begin{array}{l}\text { Customer } \\
\text { Problems }\end{array}$ & $\begin{array}{l}\text { a. Difficult to find reliable book } \\
\text { reviews in Indonesian } \\
\text { b. There are many distractions when } \\
\text { searching for book reviews on the } \\
\text { internet, especially on social media } \\
\text { like YouTube } \\
\text { c. Overwhelmed when searching for } \\
\text { book title recommendations on } \\
\text { the internet because there are too } \\
\text { many recommendations making it } \\
\text { difficult to choose a book title that } \\
\text { suits customer needs } \\
\text { d. Searching for information on } \\
\text { recommendations and book } \\
\text { reviews is quite a time consuming } \\
\text { e. Lazy looking for information } \\
\text { on recommendations and book } \\
\text { reviews }\end{array}$ & $\begin{array}{l}\text { a. The physical book stock } \\
\text { is limited, especially for } \\
\text { old books and at discount } \\
\text { book fairs } \\
\text { b. The desired book is } \\
\text { sometimes difficult to } \\
\text { find in the library }\end{array}$ & $\begin{array}{l}\text { a. Unstable motivation to read } \\
\text { books } \\
\text { b. Losing motivation to read in the } \\
\text { middle of the book } \\
\text { c. Lazy to make notes } \\
\text { d. Difficult to organize notes that } \\
\text { have been made } \\
\text { e. Difficult to find time to read a } \\
\text { book } \\
\text { f. Lazy when reading a thick book } \\
\text { g. Confused to make notes when } \\
\text { the book being read has thick } \\
\text { pages } \\
\text { h. Not focus on reading one book } \\
\text { until it's finished } \\
\text { i. Difficulty deducing the essence } \\
\text { of the book being read } \\
\text { j. Lazy to review notes that have } \\
\text { been made }\end{array}$ \\
\hline $\begin{array}{l}\text { Customer } \\
\text { expectations }\end{array}$ & $\begin{array}{l}\text { Can easily find non-fiction books as } \\
\text { needed }\end{array}$ & $\begin{array}{l}\text { Get a large selection of books } \\
\text { at competitive prices }\end{array}$ & $\begin{array}{l}\text { Can be easily understand and } \\
\text { remember information from the } \\
\text { book read }\end{array}$ \\
\hline
\end{tabular}

* Points A, B, and C are the customer activities to get nonfiction books and it's not sequence.

The identified problems obtained by empathy map canvas and customer journey mapping were raw data, furthermore, need to be synthesized through a defining process. This processes aim to narrow many problems felt by customers in order to rise the true problems that really had to be done. This process had two steps to be done, they are classifyng the ranking the problems has been identified before. The study had five problem categories, it been categorized by similarities. The categories code explained in Table 2 along with the ranking process. The problem classification had five categories.

Based on the result, the study found that frequently problem felt by customer were obstacle in finding book recommendation and book review information (code
A), followed by lacked of motivation in reading books (code C), and poor reading book management (code E).

Almost respondent felt hard to find reliable nonfiction book review, lack of recommended book information, and had an overwhelmed feeling to choose a huge number of book titles. Lacked motivation reading driven by unstable motivation when reading the book, loss motivation in the middle reading processes, feeling lazy when saw thick books, and eyestrain when reading e-book. The last poor reading management, such as hard to spare the time for reading, and no special page marker on e-book. 
Table 2. Categorization of customer problems

\begin{tabular}{|c|c|c|}
\hline Codes & Customer problems & Frequency* \\
\hline $\mathbf{A}$ & Obstacle in finding recommendation and book review information & \\
\hline M1 & Hard to find reliable nonfiction book reviews in Indonesian & 27 \\
\hline M4 & Lack of recommended book information & 27 \\
\hline M2 & Overwhelmed when searching for book title on the internet that met your needs & 20 \\
\hline M3 & Hard to determine keyword when searching for book reviews on the internet, & 15 \\
\hline M5 & Lazy looking for information on recommendations and book reviews & 8 \\
\hline B & Constraints to purchase / rent the books & \\
\hline M6 & The physical book stock is limited, especially old books. & 2 \\
\hline M7 & The desired books sometimes difficult to find in the library & 1 \\
\hline $\mathbf{C}$ & Lack of motivation in reading books & \\
\hline M8 & Motivation to read books that are unstable & 30 \\
\hline M9 & Loss of motivation to read in the middle of the book & 29 \\
\hline M10 & Lazy when reading a thick book & 4 \\
\hline D & Constraints in making notes & \\
\hline M11 & Lazy to make notes & 27 \\
\hline M12 & Difficult to organize notes that have been made & 3 \\
\hline M13 & Confused to make notes when the book being read has thick pages & 1 \\
\hline $\mathbf{E}$ & Poor reading management & \\
\hline M15 & Difficult to find time to read a book & 28 \\
\hline M16 & Not focus on reading one book until it's finished & 5 \\
\hline M17 & Difficulty deducing the essence of the book being read & 1 \\
\hline M14 & Lazy to review notes / notes that have been made & 3 \\
\hline
\end{tabular}

\section{Managerial Implications}

Based on the result of this study, most respondents felt hard to find reliable non-fiction book review, lack of recommended book information, and had an overwhelmed feeling to choose a huge number of book titles. Those can be solved with an AI (artificial intelligence) made by IT company in work with the Ministry of Culture, Education, Research, Technology, and High Education in Indonesia. IT company, the ministry, and book publishers can work together to make an application in smartphone/ tablet. This application needs users to sign up, and in the process of signing up, users are asked to choose their interests or book's genre related to their jobs. There are so many applications used this as the process of signing up; like Spotify, TikTok, Netflix; to make users easy to find what they like to enjoy (listen or watch). This technology also can be applied to the applications for reading non-fiction books online from smartphone.

\section{CONCLUSIONS AND RECOMMENDATIONS}

\section{Conclusions}

Frequently problem occurred by smart phone user while reading nonfiction book categorized into five problem section, such as Obstacle in finding recommendation and book review information (Code A), Constraints to purchase / rent the books (code B), Lack of motivation in reading books (code $\mathrm{C}$ ), Constraints in making notes (code D), and Poor reading management (code E). The most problem felt by user is lacked of reading motivation which is driven by unstable feeling or motivation while reading a book, loosed motivation in the middle of reading process, and felt lazy when saw thick book. The second is obstacles in finding recommendation and book review information. Those user experiences felt by smart phone user could be driven as ideation to develop platform which is help user in exploring and reading nonfiction book. 


\section{Recommendations}

The limitation on this study not carried out emersion process on interview process, due to spread out Corona Virus since February 2020. The emersion process should be carried out on human centered study. Further research might applied testing the problems to verified the user experiences obtained by this study before continuing to ideation and prototyping stage in develop platform.

\section{REFERENCES}

Central Connecticut State Univesity. 2016. World's most literate nations ranked. https://www.ccsu. edu/wmln/rank.html/ [2020 Mar 03].

Evans DS, Schmalensee R. 2007. Catalyst Code: the Strategies Behind the World's Most Dynamic Companies. Boston: Harvard Business Press

Gray D. 2017. Updated Empathy Map Canvas. https:// medium.com/the-xplane-collection/updatedempathy-map-canvas-46df22df3c8a [2020 Jun 20].

Jonash R, Koehler H, Onassis I. 2007. The power of platforms. Business Strategy Series 8(1): 26-34.

Kim J. 2015. The platform business model and strategy: a dynamic analysis of the value chain and platform Business [dissertation]. The University of Manchester

Kotler P, Armstrong G. 2010. Principles of marketing. London: Pearson Education.

Liedtka J, Ogilvie T. 2011. Designing for growth: A Design Thinking Tool Kit for Managers. New York: Columbia University Press.

[PISA] Programme for International Student Assessment. 2018. Insight and Interpretations. https://www.oecd-ilibrary.org/education [2020 Mar 03].

Punch KF. 2013. Introduction to Social Research: Quantitative and Qualitative Approaches. London: Sage Publications

Statista. 2018. Share of time spent on mobile phones in Indonesia as of August 2018. https://www. statista.com/statistics/1021669/indonesia-shareof-mobile-phone-time-usage-by-activity/ [2020 Jun 09].

Tajibu K. 2013. Metode Penelitian Komunikasi. Makassar: Alauddin University Press.

Urban T. 2013. Why Procrastinators Procrastinate. https://waitbutwhy.com/2013/10/whyprocrastinators-procrastinate.html. [2020 Jun 13].

Wahyuni S. 2016. Qualitative Research Method: Theory and Practice. Bogor: Salemba Empat. 